\title{
PARITY AS A RISK FACTOR OF CHILDREN WITH CLEFT LIP
}

\author{
Nurina Widayanti ${ }^{*}$, Amira Danila ${ }^{1}$, Wahyu Indra Syohanda ${ }^{1}$
}

Background: Cleft lip and palate is one of the most common congenital anomalies with the prevalence of 1 case for every 1000 birth. Nulliparity has been associated with increased of many birth defects. In contrast, multiparity has also been associated with several birth defects.

Methods: This case-control study compares data from 74 cleft lip patients who was enrolled in Gentur Cleft Foundation to those of 87 normal children. The dependent variable of this study was the incidence of CL/P (cleft lip with or without cleft palate) and the independent variables were maternal parity. Binary logistic regression was used to analyze crude and adjusted OR. Nulliparous mothers were treated as the reference category.

Result: Compared to nulliparous mothers, primiparous mothers has OR 1.57 (95\% CI=0.78-3.2). While multiparous mothers has OR $27.54(95 \% \mathrm{CI}=3.5-216.32)$. P-value was insignificant for the association of primiparous mothers with $\mathrm{CL} / \mathrm{P}$

Conclusion: We observe higher incidence of multiparous mothers with the incidence of CL/P compared to nulliparous mothers.

Keyword: parity, risk factors, cleft lip palate.

Latar Belakang : Sumbing bibir dan langit - langit adalah kelainan bawaan paling umum dengan angka kejadian 1 kasus dari setiap 1000 kelahiran. Nullipara dikaitkan dengan meningkatnya kasus kecacatan lahir. Sebaliknya multipara juga berkaitan dengan beberapa kasus kecacatan lahir.

Metodologi : Studi kasus ini membandingkan data yang dimiliki Gentur Cleft Foundation sebanyak 74 pasien bibir sumbing dibandingkan dengan 87 orang anak normal. Penelitian ini menggunakan variable dependen berupa angka kejadian bibir sumbing dengan atau tanpa sumbing langit - langit. Dan variable independen nya adalah jumlah paritas ibu. Untuk menganalisa data menggunakan metode regresi logistic biner. Nulipara dijadikan sebagai kategori referensi.

Hasil: Dibandingkan dengan nullipara, ibu dengan primipara memiliki OR $1.57(95 \% \mathrm{CI}=0.78-3.2)$. Sementara ibu dengan multipara mempunyai OR 27.54 (95\% CI=3.5-216.32). Nilai P didapati tidak signifikan untuk ibu dengan primipara dengan bibir sumbing dengan atau tanpa sumbing langit - langit

Kesimpulan : Kami mengamati meningkatnya resiko kejadian pada ibu dengan multipara dengan kejadian bibir sumbing dengan atau tanpa sumbing langit - langit dibandingkan dengan ibu nullipara.

Kata Kunci : parity, risk factors, cleft lip palate. 


\section{INTRODUCTION}

Cleft lip is a gap on the upper lip and in many cases the lip gap may be accompanied by palate gap that cause direct connection between mouth and nose 1,2. There are several studies that have been published to investigate the etiology of cleft lip with or without cleft palate (CL/P), researchers are still in debate about the etiology either genetics or the environment, many of the previous studies addressed a number of risk factors such as the role of folic acid, oral contraceptives, maternal exposure to smoking and alcohol, maternal age, parity, pregnancy complication, and history of CLP in family ${ }^{3}$.

Parity is the number of live birth before the index delivery ${ }^{4}$. Nulliparous is a woman who never have live birth before the index delivery. Primiparous is a woman who have one live birth before the index delivery. Multiparous is a woman who have two or more live birth before the index delivery 5,6 .

Many studies have observed a correlation between parity and risk factor for birth defects, though in previous studies showed that nulliparity was associated with an increased risk of specific phenotypes of birth defects, but there're no specific studies that explain about its correlation with cleft lip. This study aims to compare parity and risk factors associated between women with normal child and women who have child with CL/P.

\section{METHODS}

This case-control study acquires sample data of 74 cleft lip patients from Gentur Cleft Foundation (GCF) year 2014 to 2015. With the exclusion criteria of syndromic cleft lip, we excluded 1 case of patient with Pierre-Robin Sequence. Isolated cleft palate were not analyzed because of limited source of data. Control group data were obtained from 87 normal children whose parents were asked with the same questionnaire.

The incidence of $\mathrm{CL} / \mathrm{P}$ was treated as the dependent variable. Parity was treated as independent variable with nulliparous mothers chosen as the reference category. Crude and adjusted Odd Ratios (ORs) were calculated using binary logistic regression. Odd ratios were adjusted for maternal age and contraception usage. All calculation was done with SAS University Edition.

\section{RESULT}

Male predominance was noted in CL/P group $(62.16 \%)$ as well as in control group (52.87\%). In Table 1, maternal age was categorized into four groups: $\leq 24,25-29,30-34$, and $\geq 35$ years old. Maternal age 25-29 years old has the highest percentage in both groups. In CL/P group, there are $48.65 \%$ nulliparous mothers, $29.73 \%$ primiparous mothers, and $21.62 \%$ multiparous mothers. They were compared to $71.26 \%$ nulliparous mothers, $27.59 \%$ primiparous mothers, $1.15 \%$ multiparous mothers in control group. The use of contraception in both group were minimal, $8.11 \%$ in CL/P group and 6.90\% in control group. Greater number of samples with positive family history of cleft were observed in CL/P (21.43\%) compared to control group (6.9\%).

Shown in Table 2 were risk estimates of parity to the incidence of $\mathrm{CL} / \mathrm{P}$. Crude risk estimate of primiparous mothers compared to nulliparous mothers were 1.58 (95\% CI $0.78-3.21$ ) times, although p-value was insignificant. After adjusted for maternal age, gender, and family history of cleft, risk estimate calculation increased to 2.73 (95\% CI 0.875-4.790) with insignificant p-value. Multiparous mother has the highest crude risk estimate (Crude OR=27.54, 95\% CI 3.51-216.32) compared to nulliparous mothers. Multiparous risk estimate was even higher after adjusted to maternal age, gender, and family history of cleft (Adjusted OR=29.12, 95\% CI 3.20-264.64

Disclosure: The authors have no financial interest to disclose. 
Table 1. Data of the patients

\begin{tabular}{lcc}
\hline \multicolumn{1}{c}{ Characteristic } & $\begin{array}{c}\text { CL/P } \\
\mathbf{n}=\mathbf{7 4}(\%)\end{array}$ & $\begin{array}{c}\text { Control } \\
\mathbf{n = 8 7}(\%)\end{array}$ \\
\hline $\begin{array}{l}\text { Gender } \\
\text { Male }\end{array}$ & $46(62.16)$ & $46(52.87)$ \\
Female & $28(37.84)$ & $41(47.13)$ \\
Maternal Age & & \\
$\leq 24$ & $12(16.22)$ & $3(3.45)$ \\
$25-29$ & $26(35.14)$ & $53(60.92)$ \\
$30-34$ & $12(16.22$ & $23(26.44)$ \\
$\geq 35$ & $22(29.73)$ & $8(9.20)$ \\
Parity & & $62(71.26)$ \\
Nulliparous & $36(48.65)$ & $24(27.59)$ \\
Primiparous & $22(29.73)$ & $1(1.15)$ \\
Multiparous & $16(21.62)$ & \\
Contraception & & $6(6.90)$ \\
Yes & $6(8.11)$ & $73(83.91)$ \\
No & $63(85.14)$ & $6(6.90)$ \\
Other (unknown/ forget) & $2(2.7)$ & $61(9.9)$ \\
Family history of cleft & $15(21.43)$ & $81.10)$ \\
Yes & $55(78.57)$ & \\
No & &
\end{tabular}

Table 2. Mother's parity

\begin{tabular}{lccc}
\hline & \multicolumn{3}{c}{$\begin{array}{c}\mathrm{CL} / \mathrm{P} \\
\mathrm{n}=74\end{array}$} \\
Parity & $\begin{array}{c}\text { Crude OR } \\
(95 \% \mathrm{CI})\end{array}$ & $\begin{array}{c}\text { Control } \\
\mathrm{n}=87(\%)\end{array}$ \\
\cline { 2 - 4 } Nulliparous & 1.00 (Reference) & $1.00($ Reference) & $62(71.26)$ \\
Primiparous & $1.58(0.78-3.21)$ & $2.73(0.875-4.790)$ & $24(27.59)$ \\
Multiparous & $27.54(3.51-216.32)^{*}$ & $29.12(3.20-264.64)^{*}$ & $1(1.15)$ \\
\hline
\end{tabular}

\section{DISCUSSION}

In this study we found that multiparous mothers have the highest risk estimate for the incidence of $\mathrm{CL} / \mathrm{P}$ compared to nulliparous mothers. Although p-value for multiparous mothers was significant, the confidence interval was very wide suggesting low statistical certainty ${ }^{7}$. This wide confidence interval can be caused by small number and high variability of samples in this study. In contrast, primiparous mothers were insignificant for CL/P risk estimates when compared to nulliparous mothers. We also tried to conduct multivariate analysis by cross interacting parity with other covariates, but the results showed there were no significant interactions.
Compared to primiparous women, nulliparous women were more likely to have offspring with eight noncardiac birth defect phenotypes: amniotic band sequence, hydrocephaly, esophageal atresia, hypospadias, limb reduction deficiencies, diaphragmatic hernia, omphalocele and gastroschisis 5 nulliparous control mothers were younger, more likely to binge drink, smoke, have gestational hypertension, and have undergone fertility treatment ${ }^{5}$.

In contrast, Messer et al. had proposed that slightly larger proportion of nonsyndromic $\mathrm{CL} / \mathrm{P}$ cases were born to women with three or more prior births in Texas during 1999-2003 8 . 
However, Luo et al data did not support the relation between parity and the $\mathrm{CL} / \mathrm{P}$, the crude model for CL $/ \mathrm{P}$ pointed to a $52 \%$ increased risk for women with parity $\geq 2(\mathrm{OR}=1.52,95 \% \mathrm{CI}$ 0.95-2.46), yet this risk estimate decreased and turned out to be non-statistical significant in the adjusted model, with an OR of 1.34 (95\% CI 0.812.23) ${ }^{9}$. In their meta-analysis study, Vieira and Orioli also found an increase in the risk of oral clefts with increasing parity. For parity of 4 or more, they reported an odds ratio of 3.12 (CI $1 / 4$ 2.58-3.77) for nonsyndromic CL/P and an odds ratio of 3.35 (CI $1 / 4$ 2.39-4.69) for nonsyndromic cleft palate only ${ }^{10}$.

Our result is also similar to studies by Golalipour et al in mothers with parity greater than 2 there was a significantly increased risk of having a child with an oral cleft compared with mothers whose parity was $1(\mathrm{OR}=3.33$, CI 95\% [1.2, 9.19], $\mathrm{P}<0.02)$. The association they observed between parity and an increased risk of oral clefts may be due to the physiological condition of the mother, as increased parity may have adverse effects on micronutrients and subsequently increase the risk of oral clefts ${ }^{11}$. Epidemiological data confirm that multiparous women are more at risk of becoming iron deficient and anemic ${ }^{12}$. In analysis using parity as a categorical variable, Glosz study remained significant. Primiparous women had significantly higher baseline ferritin concentrations (mean $64.4 \mathrm{ng} / \mathrm{mL}$ ), compared to multiparous women (mean $39.0 \mathrm{ng} / \mathrm{mL}$, p-value $<0.0001)$. Lower hemoglobin concentrations (mean $9.7 \mathrm{~g} / \mathrm{dL}$ ) compared to multiparous women $(10.1 \mathrm{~g} / \mathrm{dL}) \quad(\mathrm{p}=0.03)$. Primiparous women had significantly higher hair zinc concentrations (but not plasma zinc) compared to multiparous women ${ }^{13}$.

Due to small number of samples, we cannot generalize the results as it may differ in various populations. The risk of selection bias is also high since there has not been any population-base registry in our country. From this findings, we suggest conducting similar research with bigger samples and more covariate variables. We also suggest for multiparous mothers to look carefully on their dietary micronutrient intake.

\section{CONCLUCION}

In this study we found that multiparous mothers have the highest risk estimate for the incidence of CL/P compared to nulliparous mothers. In contrast, primiparous mothers were insignificant for CL/P risk estimates when compared to nulliparous mothers. However, due to small number of samples, we cannot generalize the results as it may differ in various populations.

\section{Acknowledgment}

The authors acknowledge GCF for providing patient data for this research. Conflict of interest: none declared.

Corresponding author :

Nurina Widayanti

wida.nurina@gmail.com.com

\section{REFERENCES}

1. Sudjatmiko G. Mengenal Sumbing. Jakarta: Yayasan Lingkar Studi Bedah Plastik. 2014. p.

2. Sudjatmiko G. Petunjuk Praktis Ilmu Bedah Plastik Rekonstruksi Edisi IV. Jakarta: Yayasan Lingkar Studi Bedah Plastik. 2014. P.94.

3. Sari V. A., Anggrahita T. Pregnancy Unawareness and Risk Factors in Cleft. Jurnal Plastik Rekonstruksi. 2013. 2(2): 64-70.

4. Baird JT Jr, Quinlivan LG. Parity and hypertension. Vital Health Stat. 1972; 11:1-28

5. Duong HT, Hoyt AT, Carmichael SL et al. Is Maternal Parity an Independent Risk Factor for Birth Defects? Birth Defects Res A Clin Mol Teratol. 2012. 94(4): 230-236

6. Cunningham FG, Leveno KJ, Bloom SL et al. Williams Obstetrics 24th Edition. USA: McGraw Hill Education. P. 64.

7. Nakagawa S, Cuthill IC. Effect size, confidence interval and statistical significance: a practical guide for biologists. Biological Reviews. 2007. 82:591-605

8. Messer LC, Luben TJ, Mendola P, Carozza SE, Horel $\mathrm{SA}$, et al. Urban- rural residence and the occurrence of cleft lip and cleft palate in Texas, 1999-2003. Ann Epidemiol. 2010. 20: 32-39. 
9. Luo YL, Cheng YL, Gao XH, et al. Maternal Age, Parity and Isolated Birth Defects: A PopulationBased Case-Control Study in Shenzhen, China. PLoS ONE. 2013. 8(11).

10. Vieira AR, Orioli IM. Birth Order and Oral Clefts: A Meta Analysis. Teratology. 2002. 66:209-216.

11. Golalipour MJ, Kaviany N, Qorbani M, Mobasheri E. Maternal Risk Factors for Oral Clefts: A CaseControl Study. Iranian Journal of Otorhinolaryngology. 2012. 4(24):190.

12. Howson CP, Kennedy ET, Horwitz A. Prevention of micronutrient deficiencies: tools for policymakers and public health worker. Washington D.C: National Academy Press. 1998. p.66.

13. Glosz CM. Assessment of Micronutrient Status in Pregnant Malawian Women Before and After Treatment for Moderate Malnutrition. Master [Thesis]. San Luis Obispo: Faculty of California Polytechnic State University. 2016. 